\title{
CHANGES IN THE TRACHEAL EPITHELIUM DURING 24 HOURS AFTER INHALATION OF MINERAL WATER
}

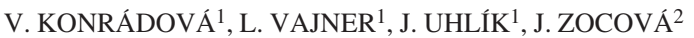 \\ ${ }^{1}$ Institute of Histology and Embryology, $2^{\text {nd }}$ Medical Faculty and ${ }^{2}$ Department of Applied Mathematics \\ and Computer Science, Faculty of Science, Charles University, Prague, Czech Republic \\ Received January 9, 2001 \\ Accepted May 28, 2001 \\ Abstract \\ Konrádová, V., L. Vajner, J. Uhlík, J. Zocová: Changes in the Tracheal Epithelium \\ during 24 Hours after Inhalation of Mineral Water. Acta Vet. Brno 2001, 70: 167-172. \\ Inhalation of aerosol of mineral water is frequently used in therapy of various respiratory \\ disorders. Ultrastructure of the airway epithelium in rabbits and character of glycoconjugates \\ produced by secretory cells were studied immediately and $24 \mathrm{~h}$ after 10 -min inhalation of this \\ aerosol. Goblet cells were overstimulated and the mechanism of mucus evacuation was \\ accelerated. The exhausted goblet cells mostly took part in further secretory cycles, but the number \\ of degenerated secretory elements gradually increased in the course of $24 \mathrm{~h}$. Cells not entirely filled \\ with secretory granules prevailed in the epithelium. Massive differentiation of goblet cells and \\ development of intraepithelial mucous glands were noticed. Compared with controls, significant \\ $(\alpha=0.01)$ decrease in the acid sulphated glycoconjugates in the secretion of the goblet cells was \\ accompanied by an increase of the acid sialylated ones immediately after inhalation. Twenty-four \\ hours post exposure, significant $(\alpha=0.05)$ decrease in total sialylated glycoconjugates was \\ ascertained. The ciliated cells revealed only mild pathological alteration. Significant $(\alpha=0.01)$ \\ decrease in number of kinocilia/ $\mu \mathrm{m}^{2}$ was accompanied by an increase in percentage of altered cilia. \\ During $24 \mathrm{~h}$ post exposure, signs of ciliary border regeneration were noticed. Morphological signs \\ of impaired self-cleaning ability of the airway epithelium were encountered during the whole \\ experiment. Single 10-min inhalation of mineral water aerosol caused changes in the ultrastructure \\ of the airway epithelium and influenced the chemical composition of the goblet cells' secretion. \\ These changes did not disappear completely during $24 \mathrm{~h}$ post exposure.
}

Airways, ultrastructure, regeneration, lectin histochemistry, glycoconjugates, rabbit

In our previous study, we demonstrated that 10-min inhalation of saline affected the ultrastructure of the airway epithelium (Konrádová et al. in press). We therefore decided to study also the effect of aerosol of mineral water, frequently used in therapy of various respiratory disorders, and to follow the process of regeneration of this epithelium in the course of $24 \mathrm{~h}$.

\section{Materials and Methods}

In our experiments, 19 SPF New Zealand White rabbits (body weight 1,500-3,000 g, Charles River Deutschland, Sulzfeld, Germany) were used. Seven of them served as untreated controls. The remaining animals were placed successively for $10 \mathrm{~min}$ into a plastic cage connected with the inhalation device PARI Master and nebuliser PARI LL (Pari GmbH, Starnberg, Germany, medium diameter of produced droplets $3.1 \mu \mathrm{m}$, total output $0.6 \mathrm{~g} / \mathrm{min}$ ). The rabbits inhaled an aerosol of mineral water for $10 \mathrm{~min}$. Chemical composition of this spring water is given in Tab. 1. Under general anaesthesia, the material for electron microscopic and histochemical examinations was collected from six animals immediately and $24 \mathrm{~h}$ post exposure, respectively.

Tiny fragments of the tracheal mucous membrane were processed using standard methods for electron microscopy (Konrádová 1991). The ciliary border and the functional state of the goblet cells were evaluated quantitatively. To evaluate the distribution of goblet cells in the epithelium, the isolated elements and the goblet cells arranged in groups were distinguished. Kinocilia were classified into four categories: intact 9+2 cilia, slightly damaged pathological cilia with local swellings of the ciliary membrane or with tiny vacuoles situated in their shafts, degenerating cilia, represented by axonemes incorporated into cytoplasmic blebs or by isolated axonemes, and malformed cilia with either abnormal arrangement or number of microtubules in their axonemes.

Address for correspondence:

Prof. MUDr. V. Konrádová, DrSc.

Institute of Histology and Embryology

V Úvalu 84, CZ-150 06 Prague 5, Czech Republic
Phone: +420224435980

Fax: +4202 24435820

a@lfmotol.cuni.cz 
Table 1

Chemical composition of the inhaled mineral water

\begin{tabular}{|l|c|l|l|l|l|l|c|}
\hline & $\mathrm{mg} / \mathrm{l}$ & & $\mathrm{mg} / \mathrm{l}$ & & $\mathrm{mg} / \mathrm{l}$ & & $\mathrm{mg} / \mathrm{l}$ \\
\hline $\mathrm{Li}^{+}$ & 13.48 & $\mathrm{Zn}^{2+}$ & 0.0023 & $\mathrm{Fe}$ & 3.810 & $\mathrm{NO}_{2}^{-}$ & 0.00 \\
\hline $\mathrm{Na}^{+}$ & 3292.0 & $\mathrm{Cd}^{2+}$ & 0.000003 & $\mathrm{Co}^{2+}$ & 0.0003 & $\mathrm{NO}_{3}^{-}$ & 0.00 \\
\hline $\mathrm{K}^{+}$ & 160.5 & $\mathrm{Hg}$ & $<0.0001$ & $\mathrm{Ni}^{2+}$ & 0.0001 & $\mathrm{HPO}_{4}^{2-}$ & 0.039 \\
\hline $\mathrm{NH}_{4}^{+}$ & 13.16 & $\mathrm{Al}$ & 0.359 & $\mathrm{U}^{\mathrm{III}}$ & $<0.0005$ & $\mathrm{HAsO}_{4}^{2-}$ & 0.003 \\
\hline $\mathrm{Cu}^{2+}$ & 0.0316 & $\mathrm{~Pb}^{2+}$ & 0.00008 & $\mathrm{~F}^{-}$ & 2.932 & $\mathrm{HCO}_{3}^{-}$ & 6010.0 \\
\hline $\mathrm{Be}^{2+}$ & 0.00157 & $\mathrm{~V}^{\mathrm{IV}}$ & 0.00370 & $\mathrm{Cl}^{-}$ & 2319.0 & $\mathrm{HBO}_{2}$ & 413.0 \\
\hline $\mathrm{Mg}^{2+}$ & 15.07 & $\mathrm{Cr}$ & 0.0016 & $\mathrm{Br}^{-}$ & 9.068 & $\mathrm{H}_{2} \mathrm{SiO}_{3}$ & 1.19 \\
\hline $\mathrm{Ca}^{2+}$ & 258.5 & $\mathrm{Mo}^{\mathrm{VI}}$ & 0.0001 & $\mathrm{I}^{-}$ & 8.993 & $\mathrm{CO}_{2}$ & 1984.0 \\
\hline $\mathrm{Sr}^{2+}$ & 5.245 & $\mathrm{UO}_{2}^{2+}$ & $<0.0005$ & $\mathrm{HS}^{-}$ & 0.00 & & \\
\hline $\mathrm{Ba}^{2+}$ & 11.02 & $\mathrm{Mn}^{2+}$ & 0.458 & $\mathrm{SO}_{4}^{2-}$ & 0.50 & & \\
\hline
\end{tabular}

In the paraffin-embedded material, the methods of conventional histochemistry (Alcian Blue/AB/pH 2.5 - PAS and $\mathrm{AB} \mathrm{pH}$ 1.0) as well as of in situ lectin histochemistry were employed (Vajner 1998). Maackia amurensis agglutinin /MAA/ (Boehringer, Mannheim, Germany), Sambucus nigra agglutinin /SNA/ (Boehringer, Mannheim, Germany), and Tritrichomonas mobilensis lectin /TML/ (Calbiochem, La Jolla, USA) were used. Combination of these histochemical methods recognises neutral, acid sulphated and acid sialylated $[\alpha(2-3), \alpha(2-6)$ and total] glycoconjugates (GCs) in the goblet cells' secretion.

In controls, immediately and $24 \mathrm{~h}$ after inhalation of mineral water $1.058 \mu \mathrm{m}^{2}, 2,057 \mu^{2}$ and $1,300.25 \mu \mathrm{m}^{2}$ of ciliary border with 10,252,13,040 and 9,294 kinocilia were evaluated, respectively. In those experimental groups also a total of 186, 567 and 344 goblet cells using electron microscopy and 398, 379 and 422 goblet cells in histochemical studies were studied, respectively. For statistical evaluation of the ultrastructural findings, relative values of 2 categories of goblet cells and 4 categories of cilia were evaluated by the chi-square test of homogeneity in frequency tables. To specify categories causing deviations from the hypothesis of homogeneity, adjusted standardised deviations were used. In histochemical studies, relative values of six categories of goblet cells, revealed by individual methods, were evaluated in similar manner described above. The Yates' correction in low frequencies was used when appropriate. The equivalency of the sialylated glycoconjugate detecting methods was tested by the paired t-test, median (sign) test and Wilcoxon's paired test. Means of cilia/ $\mu^{2}{ }^{2}$ were compared by the one-way analysis of variance (ANOVA). The differences between groups were assessed by the Tukey's test or Bonferroni's method for multiple comparison. The Levene's test for equal variances was also performed. As a nonparametric analogy of the ANOVA, the Kruskal-Wallis test was used.

\section{Results}

\section{Control Rabbits}

In control rabbits, the tracheae were lined with a pseudostratified columnar ciliated epithelium. The ciliated cells of standard ultrastructure were the most numerous in the epithelium.

Goblet cells mostly filled with mucus were scattered among the ciliated ones. Only $6 \pm 3 \%$ of them were arranged in tiny groups. By means of gradual evacuation of the individual apical mucous granules, $3 \%$ of secretory elements discharged their secretion. The conventional histochemistry revealed the dominance of goblet cells containing acid GCs. The proportion of sulphated GCs, detected by classic histochemistry, and the total percentage of goblet cells containing sialylated GCs visualised by the reactions with lectins were given in Tab. 2 .

In the regular ciliary border, $9.7 \pm 0.3$ cilia per $1 \mu^{2}$ were found. $98.8 \pm 0.1 \%$ of cilia were intact. The proportions of pathological, degenerating and malformed cilia were given in Fig. 1.

Immediately after 10-min inhalation of mineral water

Tracheae of the rabbits exposed to mineral water aerosol were lined with an altered pseudostratified ciliated epithelium with narrow intercellular spaces and intact apical junctional complexes (Plate IV, Fig. 2). 
Table 2

Quantitative evaluation of the chemical composition of glycoconjugates (GCs) in goblet cells of the tracheal epithelium in control rabbits and in rabbits immediately and $24 \mathrm{~h}$ after 10 -min inhalation of aerosol of mineral water (relative values)

\begin{tabular}{|l|c|c|c|}
\hline & Control rabbits & $\begin{array}{c}\text { Immediately } \\
\text { after inhalation }\end{array}$ & $\begin{array}{c}24 \text { h after } \\
\text { inhalation }\end{array}$ \\
\hline Total acid GCs (AB pH 2.5 - PAS) & $98.52 .4 \%$ & $97.40 .6 \%$ & $98.81 .0 \%$ \\
\hline Neutral GCs (AB pH 2.5 - PAS) & $1.52 .4 \%$ & $2.60 .6 \%$ & $1.21 .0 \%$ \\
\hline Acid sulphated GCs (AB pH 1) & $71.96 .4 \%$ & $* 61.520 .2 \%<$ & $>77.020 .8 \%$ \\
\hline$(2-3)$ sialylated GCs (MAA) & $27.98 .4 \%$ & $* 37.213 .0 \% \prec$ & $>22.318 .4 \%$ \\
\hline (2-6) sialylated GCs (SNA) & $2.32 .9 \%$ & $* 0 \%$ & $0.71 .0 \%$ \\
\hline Total sialylated GCs (MAA + SNA) & $30.29 .6 \%$ & $\# 37.216 .0 \% \prec$ & $>\# 23.019 .1 \%$ \\
\hline Total sialylated GCs (TML) & $26.611 .5 \%$ & $* 36.919 .4 \% \prec$ & $>\# 20.114 .1 \%$ \\
\hline
\end{tabular}

Values are expressed as mean $\pm \mathrm{SD}$, values designated

* differ significantly $(\alpha=0.01)$ from controls, values designated

\# differ significantly $(\alpha=0.05)$ from controls, values connected by double arrows differ significantly $(\alpha=0.01)$ from each other

AB - Alcian Blue

MAA - Maackia amurensis agglutinin

SNA - Sambucus nigra agglutinin

TML - Tritrichomonas mobilensis lectin

In the epithelium, $34 \pm 1 \%$ of goblet cells took part in the formation of small intraepithelial mucous glands. Less than $10 \%$ of the goblet cells were filled with large light mucous granules, $4 \%$ of them were completely exhausted, their cytoplasm was highly electron dense.

Cells not entirely filled with mucus prevailed in the epithelium. These cells were equipped with short irregular microvilli and only a few small, highly electron dense granules or more numerous granules of various electron density were observed in their cytoplasm (Figs. 2, 3). In some smaller granules with typical fibrogranular matrix, electron dense cores were revealed (Plate IV, Figs. 3, 4). Also cells rich in smaller typical mucous granules separated by voluminous cytoplasmic septa were encountered (Plate IV, Fig. 5).

Mucus filled cells as well as cells containing only isolated secretory granules often discharged secretion. Evacuation of apical mucous granules, detachment of whole packets of granules and also chain fusion of the adjacent mucous granules' membranes were noticed.

Compared with controls, significant $(\alpha=0.01)$ decrease in number of goblet cells containing acid sulphated GCs was detected using methods of conventional histochemistry. Lectin histochemistry revealed slight, but significant increase in total number of goblet cells containing sialylated GCs (Tab. 2).

The ciliated cells were less damaged compared to the secretory ones. On their apical portions, only isolated small cytoplasmic blebs were developed. In the deeper portions of ciliated cells' cytoplasm, a slight increase in the number of small vacuoles, secondary lysosomes, dilatation of the cisternae of granular endoplasmic reticulum and Golgi complex and altered mitochondria were observed (Plate V, Fig. 6).

The regular arrangement of the ciliary border was slightly impaired. The mean number of cilia was $6.3 \pm 0.4 / \mu \mathrm{m}^{2}$. The altered elements represented $4.0 \pm 0.7 \%$. The proportions of the individual types of altered cilia were given in Fig. 1. In the area among the kinocilia, clumps or layers of inspissated secretion were observed (Plate V, Fig. 7). 
$24 \mathrm{~h}$ after $10-\mathrm{min}$ inhalation of mineral water

All the time, the tracheae of the experimental animals were lined with an altered pseudostratified ciliated epithelium. The intercellular spaces remained narrow, the apical junctional complexes were intact.

Tiny groups were formed by $41 \pm 3 \%$ of goblet cells. The goblet cells filled with large light mucous granules represented $7.5 \%$, the exhausted degenerated elements amounted to $15 \%$. Remnants of their degenerated, highly electron dense cytoplasm appeared infrequently above the epithelium.

Cells containing only a few secretory granules were most numerous in the epithelium. In their cytoplasm, medium sized granules of various electron density were encountered, but cells containing smaller mucous granules with typical fibrogranular matrix prevailed in the epithelium (Plate V, Fig. 8). Mucus filled cells as well as cells containing only isolated secretory granules often discharged secretion. Evacuation of apical mucous granules was mostly noticed.

Compared with previous experimental group, significant $(\alpha=0.01)$ increase in number

Fig. 1

Altered cilia in the tracheal ciliary border of rabbits immediately and 24 hours after 10-min. inhalation of mineral water aerosol

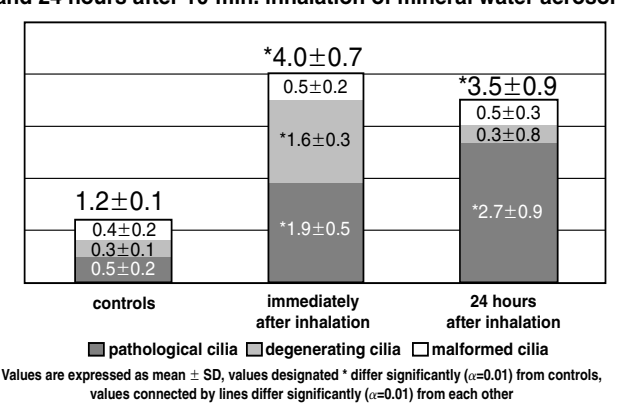
of goblet cells containing acid sulphated GCs accompanied by a decrease of total number of goblet cells containing sialylated GCs was recorded (Tab. 2).

The ciliated cells revealed only slight signs of alteration of their cytoplasm. Compared with previous experimental group, insignificant increase in mean number of cilia to $7.1 \pm 0.4 / \mu \mathrm{m}^{2}$ and decrease of altered cilia to $3.5 \pm 0.9 \%$ were noticed (Fig. 1). The amount of condensed mucus found in the area of the slightly altered ciliary border was also evidently reduced (Plate V, Fig. 9).

\section{Discussion}

The target cells for the function of mineral water aerosol were the goblet ones. Due to the 10-min inhalation of mineral water, about $90 \%$ of goblet cells were stimulated to discharge their mucus. Immediately post exposure, also the mechanism of mucus evacuation was accelerated. Signs of apocrine type of secretion and of compound exocytosis were encountered(Specian and Neutra 1980; Roumagnac and Laboisse 1987; Specian and Oliver 1991; Konrádová et al. 1996; Newman et al. 1996). After 24 h, only gradual evacuation of individual mucous granules was noticed. Immediately after aerosol administration, only a few exhausted secretory cells degenerated. The goblet cells mostly took part in further secretory cycles. The number of degenerated secretory elements gradually increased. Twenty-four h post exposure, a threefold number of degenerated cells was encountered in the epithelium.

During the whole experiment, the cells not entirely filled with secretory granules prevailed in the epithelium. Immediately post exposure, numerous cells containing small to medium sized electron dense granules were revealed. After $24 \mathrm{~h}$, the smaller mucous granules prevailed in the cytoplasm of secretory cells.

The high level of stimulation of secretory cells also induced a massive differentiation of new secretory elements (Konrádová et al. 1990, 1996). As the differentiating goblet cells retained the ability to divide (Becci et al. 1978), the result of this process were changes in their distribution in the epithelium. (Konrádová et al. 1990, 1996). In controls, less than $10 \%$ of secretory elements formed small groups in the epithelium, while more than $30 \%$ of 
them participated in the formation of intraepithelial mucous glands immediately after inhalation. The increase was highly significant $(\alpha=0.01)$. Their number even increased significantly $(\alpha=0.05)$ during the next $24 \mathrm{~h}$.

In accordance with other authors (Castells et al. 1990; Mandal and Mandal 1990; Jeffery et al. 1992), the presence of neutral, acid sulphated and sialylated GCs, the majority of acid GCs to neutral ones, and the dominance of sulphated GCs in the secretion of the goblet cells in healthy rabbits were ascertained by both conventional and lectinhistochemistry methods. The proportions of total sialylated GCs revealed by two methods of lectin histochemistry did not differ significantly.

Administration of the mineral water aerosol induced changes in the composition of GCs in the secretion of the goblet cells. Percentage of neutral GCs containing goblet cells varied non-significantly, but immediately after inhalation, a significant $(\alpha=0.01)$ decrease in the acid sulphated GCs was accompanied by an increase of the acid sialylated ones. The $\alpha(2-6)$ sialylated GCs disappeared completely from the epithelium. In our previous studies, we demonstrated that the disappearance of the $\alpha(2-6)$ sialylated GCs was one of the first signs of goblet cells overstimulation (Vajner 1998; Konrádová et al. 2000; Vajner et al. 2000). After administration of some bronchospasmolytic drugs, high level of goblet cells injury resulted in absolute predominance of acid sulphated GCs (Konrádová et al. 1997, 1998; Vajner 1998). Twenty-four h post exposure, significant decrease in total sialylated GCs was found, but the $\alpha(2-6)$ sialylated GCs reappeared in the goblet cells' secretion.

Due to the administration of mineral water aerosol, the ciliated cells were less damaged compared with the goblet ones. Slight apical blebbing and mild signs of pathological alteration were noticed in the deeper portions of the ciliated cells' cytoplasm. The tiny apical cytoplasmic protrusions were not revealed $24 \mathrm{~h}$ post exposure, but mild alteration of the cytoplasm was all the time present.

The alteration of the ciliated cells was reflected in the impairment of the ciliary border. Immediately after administration of mineral water aerosol, significant decrease $(\alpha=0.01)$ in the mean number of kinocilia/ $\mu \mathrm{m}^{2}$ was accompanied by slight, but significant $(\alpha=0.01)$ increase in percentage of altered cilia. During the next $24 \mathrm{~h}$, signs of ciliary border regeneration were noticed, but the average number of kinocilia/ $\mu \mathrm{m}^{2}$ and also the percentage of altered elements still differed significantly compared with controls $(\alpha=0.01)$.

After mineral water inhalation, condensed mucus was discovered in the area of the ciliary border. In agreement with our previous studies (Konrád ová 1991) and also with other authors who studied the relation of the cilia to the layer of mucus in the airways (Stratmann et al. 1991; Wanner et al. 1996; Geiser et al. 1997), we regarded the appearance of inspissated secretion embedding free kinocilia as a morphological sign of impaired self-cleaning ability of the airway epithelium. The signs of mucus flow impairment were most apparent immediately after aerosol administration, but to a lesser degree were still present $24 \mathrm{~h}$ post exposure.

We arrived at the conclusion that even single 10-min inhalation of mineral water aerosol caused significant changes in the ultrastructure of the airway epithelium and influenced also the chemical composition of the goblet cells' secretion and the self-cleaning ability of the epithelium. These changes did not disappear completely during $24 \mathrm{~h}$ post exposure.

\section{Změny v tracheálním epitelu v průběhu 24 hodin po inhalaci aerosolu minerální vody}

Inhalace aerosolu minerální vody je často používána jako součást terapie respiračních onemocnění. Studovali jsme ultrastrukturu a charakter glykokonjugátů produkovaných sekrečními buňkami epitelu dýchacích cest králíků ihned a 24 hodin po 10 minutové inhalaci tohoto aerosolu. Pohárkové buňky byly nadměrně stimulovány a byl urychlen mechanismus jejich sekrece. Vyprázdněné pohárkové buňky se většinou zapojovaly do dalších sekrečních cyklů, zastoupení degenerovaných sekrečních elementů se ale v průběhu 24 hodin zvyšovalo. 
Buňky, které nebyly zcela vyplněny sekrečními granuly, v epitelu převažovaly. Docházelo k masivní diferenciaci nových sekrečních elementů a ke vzniku intraepitelových hlenových žlázek. Ihned po skončení inhalace poklesl ve srovnání s kontrolami statisticky významně $(\alpha=0.01)$ počet pohárkových buněk obsahujících kyselé sulfonované glykokonjugáty a zvýšil se počet buněk obsahujících kyselé sialované glykokonjugáty. Po 24 hodinách došlo ale k významnému $(\alpha=0.05)$ snížení počtu buněk obsahujících kyselé sialované glykokonjugáty. V cytoplasmě řasinkových buněk jsme nalezli jen mírné známky patologické alterace. Došlo k významnému $(\alpha=0.01)$ snížení počtu kinocilií/ $\mu m^{2}$ a zvýšení počtu alterovaných řasinek. $\mathrm{V}$ průběhu 24 hodin se objevily známky úpravy řasinkového lemu. Během celého experimentu byly přítomny morfologické známky narušení samočisticí schopnosti epitelu dýchacích cest. Jednorázová desetiminutová inhalace aerosolu minerální vody způsobuje změny $v$ ultrastruktuře epitelu dýchacích cest a ovlivňuje i chemické složení sekretu pohárkových buněk. Tyto změny nejsou zcela reparovány ještě 24 h po inhalaci.

\section{Acknowledgements}

This work was supported by the grant No. 185/98 of Charles University Grant Agency (Prague, Czech Republic) and by the research project No 111300003 of Ministry of Education of the Czech Republic.

\section{References}

BECCI, P., McDOWELL, E. M., TRUMP, B. F. 1978: The respiratory epithelium II. J. Natl. Cancer Inst. 61: 551-561 CASTELLS, M. T., BALlESTA, J., PASTOR, L. M., MADRID, J. F., MARIN, J. A. 1990: Histochemical characterization of glycoconjugates in the epithelium of the extrapulmonary airways of several vertebrates. Histochem. J. 22: 24-35

GEISER, M., IMHOF, V., SIEGENTHALER, W., GRUNDER, R., GEHR, P. 1997: Ultrastructure of the aqueous lining layer in hamster airways. Microsc. Res. Tech. 36: 428-437

JEFFERY, P. K., GAILLARD, D., MORET, S. 1992: Human airway secretory cells during development and in mature airway epithelium. Eur. Respir. J. 5: 93-104

KONRÁDOVÁ, V. 1991: Quantitative evaluation of the degree of damage to tracheal epithelium. Func. Develop. Morphol. 1: 47-50

KONRÁDOVÁ, V., KANTA, J., ŠULOVÁ, J. 1990: Effect of bronchoalveolar lavage on the ultrastructure of the tracheal epithelium in rabbits. Respiration 57: 14-20

KONRÁDOVÁ, V., UHLÍK, J., VAJNER, L., ZOCOVÁ, J. 1996: Reaction of the goblet cells to the cholinergic stimulation. Acta Vet. Brno 65: 175-180

KONRÁDOVÁ, V., UHLÍK, J., VAJNER, L., ZOCOVÁ, J. 1997: Effect of an adrenergic agonist and a cholinergic antagonist on the airway epithelium. Vet. Med. - Czech 42: 289-293

KONRÁDOVÁ, V., UHLÍK, J., VAJNER, L., ZOCOVÁ, J. 1998: The effect of two $\beta_{2}$ adrenergic agonists on the ultrastructure of the airway epithelium in rabbits. Vet. Med. - Czech 43: 187-192

KONRÁDOVÁ, V., VAJNER, L., UHLÍK, J., ZOCOVÁ, J. 2000: The effect of Placebo-Inhaler on the tracheal epithelium in rabbits. Vet. Med.- Czech 45: 189-194

KONRÁDOVÁ, V., VAJNER, L., UHLÍK, J., ZOCOVÁ, J. in press.: Reakce epitelu dýchacích cest na inhalaci fyziologického roztoku. Studia Pneumol. Phthiseol.

MANDAL, C., MANDAL, C. 1990: Sialic acid binding lectins. Experientia 46: 433-441

NEWMAN, T. M., ROBICHAUD, A., ROGERS, D. F. 1996: Microanatomy of secretory granule release from guinea pig tracheal goblet cells. Am. J. Respir. Cell Mol. Biol. 15: 529-539

ROUMAGNAC, I., LABOISSE, C. 1987: A mucus-secreting human colonic epithelial cell line responsive to cholinergic stimulation. Biol. Cell 61: 65-68

SPECIAN, R. D., NEUTRA, M. R. 1980: Mechanism of rapid mucus secretion in goblet cells stimulated by acetylcholine. J. Cell. Biol. 85: 626-640

SPECIAN, R. D., OLIVER, M. G. 1991: Functional biology of intestinal goblet cells. Am. J. Physiol. 260: C183C193

STRATMANN, U., LEHMANN, R. R., STEINBACH, T., WESSLING, G. 1991: Effect of sulfur dioxide inhalation on the respiratory tract of the rat. Zbl. Hyg. 192: 324-335

VAJNER, L. 1998: Účinek dvou $\beta_{2}$ sympatomimetických bronchospasmolytik na podíl sialovaných a sulfonovaných glykokonjugátů v sekretu pohárkových buněk tracheálního epitelu. Čs. Patol. 34: 13-16

VAJNER, L., UHLÍK, J., KONRÁDOVÁ, V., ZOCOVÁ, J. 2000: The effect of intravenously administered acetylcholine on the glycoconjugate composition in goblet cells of the tracheal epithelium in rabbits. Acta Vet. Brno 69: 17-23

WANNER, A., SALATHÉ, M., O'RIORDAN, T. G. 1996: Mucociliary clearance in the airways. Am. J. Respir. Crit. Care Med. 154: 1868-19 
Plate IV

Konrádová V. et al.: Changes... pp. 167-172
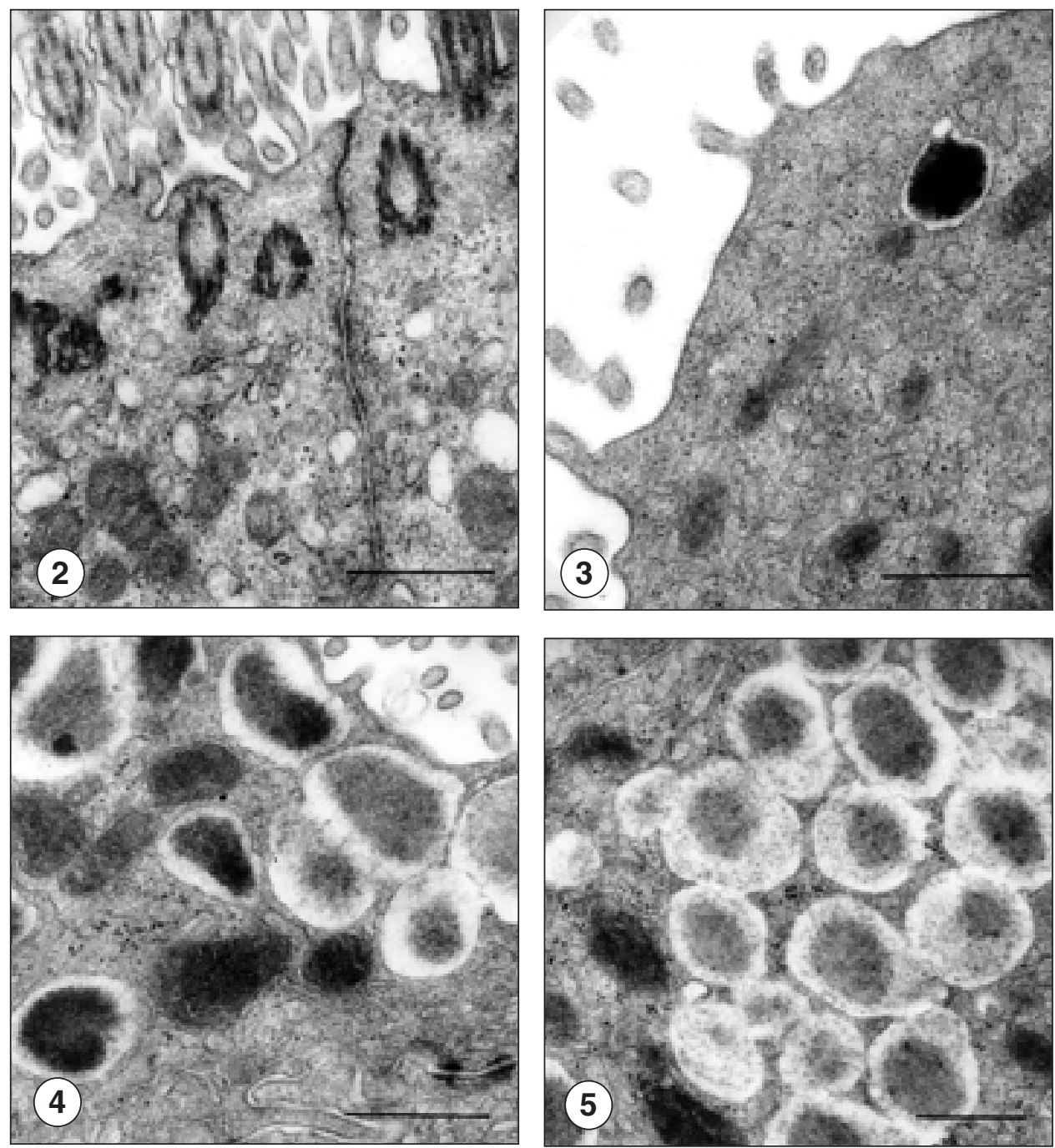

Fig. 2: Intact junctional complex in the apical portion of the epithelium. Tracheal epithelium, rabbit, immediately after 10-min inhalation of an aerosol of mineral water; bar represents $1 \mu \mathrm{m}$.

Fig. 3: Isolated small highly electron dense granule in the apical portion of a secretory cell. Tracheal epithelium, rabbit, immediately after 10-min inhalation of an aerosol of mineral water; bar represents $1 \mu \mathrm{m}$.

Fig. 4 Secretory granules of different electron density in the cytoplasm of a secretory cell. Tracheal epithelium, rabbit, immediately after 10-min inhalation of an aerosol of mineral water; bar represents $1 \mu \mathrm{m}$.

Fig. 5: Portion of the cytoplasm of a secretory cell rich in smaller mucous granules. Tracheal epithelium, rabbit, immediately after 10-min inhalation of an aerosol of mineral water; bar represents $1 \mu \mathrm{m}$. 
Plate V
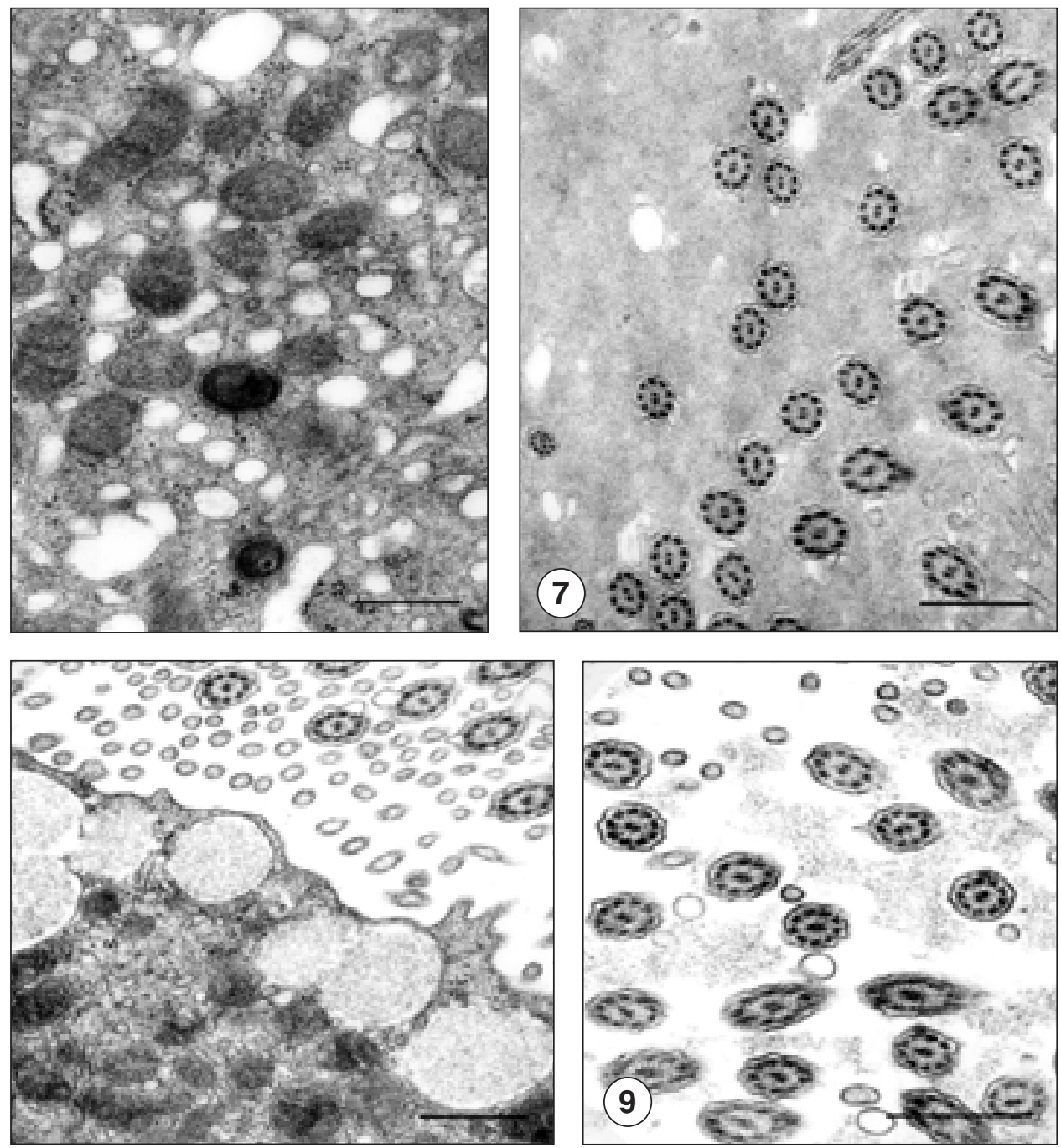

Fig. 6: Numerous tiny vacuoles and small lysosomes in the cytoplasm of a ciliated cell. Tracheal epithelium, rabbit, immediately after 10-min inhalation of an aerosol of mineral water; bar represents $1 \mu \mathrm{m}$.

Fig. 7: Layer of condensed secretion embedding free kinocilia. Tracheal epithelium, rabbit, immediately after 10min inhalation of an aerosol of mineral water; bar represents $1 \mu \mathrm{m}$.

Fig.8: Small mucous granule in the apical portion of a secretory cell. Tracheal epithelium, rabbit, immediately after 10-min inhalation of an aerosol of mineral water; bar represents $1 \mu \mathrm{m}$.

Fig.9: Clumps of condensed secretion in the area of the ciliary border. Tracheal epithelium, rabbit, immediately after 10-min inhalation of an aerosol of mineral water; bar represents $1 \mu \mathrm{m}$. 